\title{
Verzeichnis der Abbildungen
}

Tafel $1-17$

Tafel

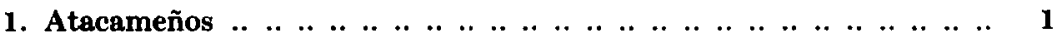

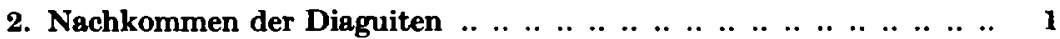

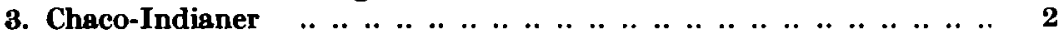

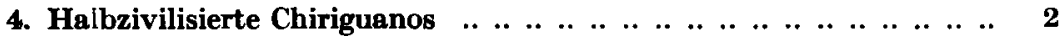

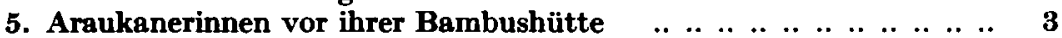

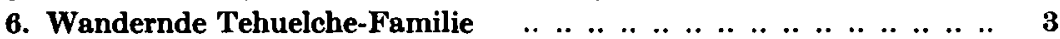

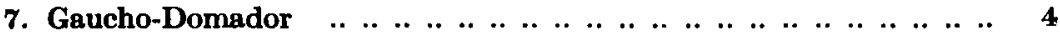

8. Argentinerin aus der ,Sociedad porteña" ${ }^{6}$. . . . . . . . . . . . . . . . . . 4

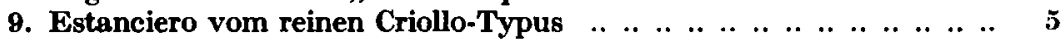

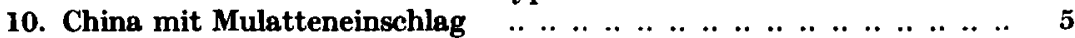

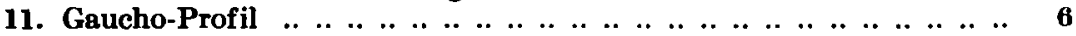

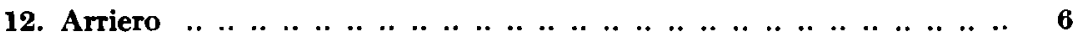

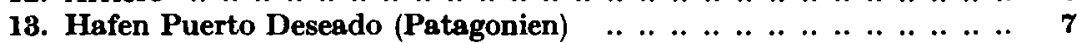

14. Petroleumfeld von Comodoro Rivadavia $\quad$.. . . . . . . . . . . . . . . . . 7

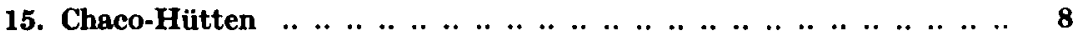

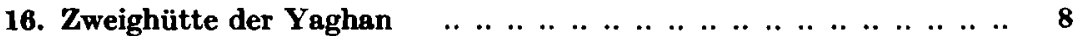

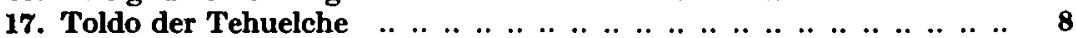

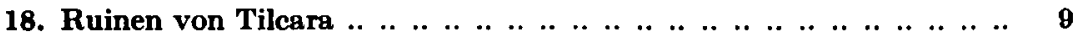

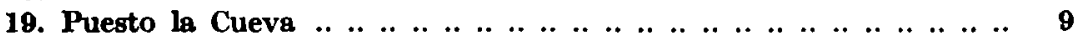

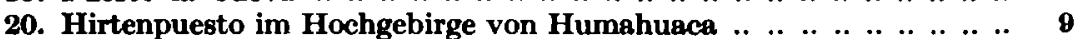

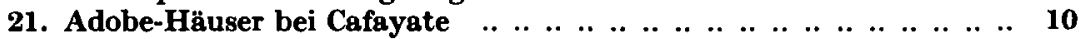

22. Puesto María Josefa

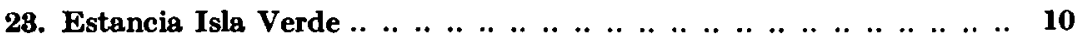

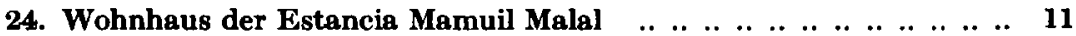

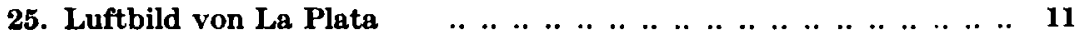

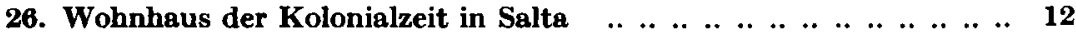

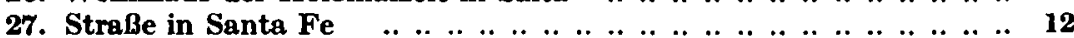

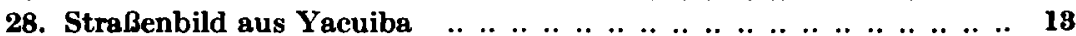

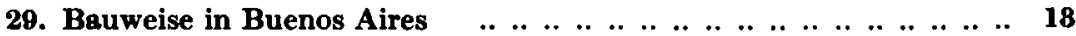

30. City von Buenos Aires mit Hochhäusern $\quad$..

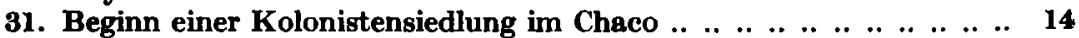

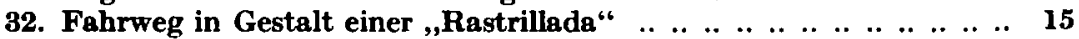

33. Mensagería (Personenpost) $\quad$. . . . . . . . . . . . . . . . . . . . . . . . . . . . . . . 15

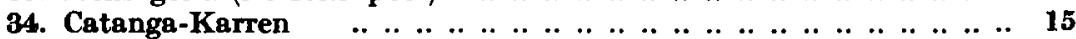

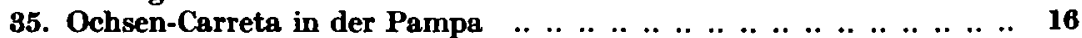

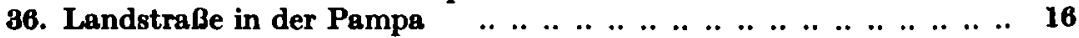

37. Der Río Paraná bei der Stadt Paraná $\quad$. . . . . . . . . . . . . . . . . . . . . 17

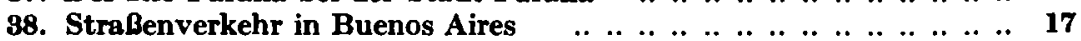

